\title{
Article \\ Directed Recovery and Molecular Characterization of Antibiotic Resistance Plasmids from Cheese Bacteria
}

\author{
Ana Belén Flórez ${ }^{1,2, * \mathbb{D}}$, Lucía Vázquez ${ }^{1,2}$, Javier Rodríguez ${ }^{1,2}$ and Baltasar Mayo ${ }^{1,2}$ (D) \\ 1 Departamento de Microbiología y Bioquímica, Instituto de Productos Lácteos de Asturias (IPLA), Consejo \\ Superior de Investigaciones Científicas (CSIC), Paseo Río Linares s/n, 33300 Villaviciosa, Spain; \\ lucia.vazquez@ipla.csic.es (L.V.); javier.rodriguez@ipla.csic.es (J.R.); baltasar.mayo@ipla.csic.es (B.M.) \\ 2 Instituto de Investigación Sanitaria del Principado de Asturias (ISPA), Avenida de Roma s/n, \\ 33011 Oviedo, Spain \\ * Correspondence: abflorez@ipla.csic.es; Tel.: +34-985-893-419
}

Citation: Flórez, A.B.; Vázquez, L.; Rodríguez, J.; Mayo, B. Directed Recovery and Molecular

Characterization of Antibiotic Resistance Plasmids from Cheese Bacteria. Int. J. Mol. Sci. 2021, 22, 7801. https://doi.org/10.3390/ ijms22157801

Academic Editor: Carlos Juan Nicolau

Received: 10 June 2021

Accepted: 19 July 2021

Published: 21 July 2021

Publisher's Note: MDPI stays neutral with regard to jurisdictional claims in published maps and institutional affiliations.

Copyright: (C) 2021 by the authors. Licensee MDPI, Basel, Switzerland. This article is an open access article distributed under the terms and conditions of the Creative Commons Attribution (CC BY) license (https:// creativecommons.org/licenses/by/ $4.0 /)$.

\begin{abstract}
Resistance to antimicrobials is a growing problem of worldwide concern. Plasmids are thought to be major drivers of antibiotic resistance spread. The present work reports a simple way to recover replicative plasmids conferring antibiotic resistance from the bacteria in cheese. Purified plasmid DNA from colonies grown in the presence of tetracycline and erythromycin was introduced into plasmid-free strains of Lactococcus lactis, Lactiplantibacillus plantarum and Lacticaseibacillus casei. Following antibiotic selection, the plasmids from resistant transformants were isolated, analyzed by restriction enzyme digestion, and sequenced. Seven patterns were obtained for the tetracyclineresistant colonies, five from L. lactis, and one each from the lactobacilli strains, as well as a single digestion profile for the erythromycin-resistant transformants obtained in L. lactis. Sequence analysis respectively identified tet(S) and ermB in the tetracycline- and erythromycin-resistance plasmids from L. lactis. No dedicated resistance genes were detected in plasmids conferring tetracycline resistance to L. casei and L. plantarum. The present results highlight the usefulness of the proposed methodology for isolating functional plasmids that confer antibiotic resistance to LAB species, widen our knowledge of antibiotic resistance in the bacteria that inhabit cheese, and emphasize the leading role of plasmids in the spread of resistance genes via the food chain.
\end{abstract}

Keywords: antibiotic resistance; horizontal gene transfer; plasmids; tetracycline and erythromycin resistance; artisanal cheeses; lactic acid bacteria

\section{Introduction}

The wide use of antibiotics in human and veterinary medicine, agriculture and aquaculture has promoted the appearance and spread of resistance to antibiotics, compromising their therapeutic effectiveness [1]. Understanding the mechanisms involved in the transmission of resistance is vital if we are to control its spread [2]. Efforts to stop it are certainly needed in clinical settings, but are also vital across interconnected ecosystems involving livestock, food, food waste, water and sewage, etc. [3-6]. Paying attention to all of these as a whole is known as the One Health approach [7].

Antibiotic resistance genes (ARG) can spread via horizontal transfer between bacteria that share the same habitat. Among the different mobile elements that may be involved, plasmids are thought to be key players. Plasmids are extrachromosomal DNA molecules that recruit the host cell machinery for their replication and copy number control [8]. The metabolic cost of plasmid replication and maintenance can place an energetic burden on bacterial cells [9], but plasmids can also encode traits that confer advantages to the host. These are frequently associated with survival and adaptation to changeable environments, including the ability to metabolize different carbon and nitrogen sources, resistance and tolerance to heavy metals, disinfectants, antibiotics, and other environmental pollutants, and the ability to synthesize antimicrobial agents [10-13]. By transferring beneficial traits 
within and between bacterial species, plasmids play an important role in these species' evolution [10]. The transfer of plasmids between bacteria can occur via conjugation, transduction, transformation, and vesiduction [14]. The presence of ARG-carrying plasmids, therefore, increases the risk of the transfer of resistance $[15,16]$; the study of such plasmids is crucial if the risk they pose to human health is to be understood, and if strategies to reduce the horizontal transfer of the genes they carry are to be developed [12].

The food chain may be a major thoroughfare for the spread of antibiotic resistance from animals to humans, particularly by consumption of fresh, little-processed, and raw-made products [17-19]. In cheese, ARG have been identified in total microbial DNA as well as in isolated bacteria. Genes coding for resistance to tetracycline, erythromycin, streptomycin, aminoglycosides, chloramphenicol and virginiamycin, have all been reported [20,21], and Southern blotting and genome sequencing have shown many of these genes to be carried by plasmids [22-24]. Both narrow and broad host-range ARG-carrying plasmids have been frequently detected in Gram-negative bacteria isolated from food $[25,26]$. However, the abundance, diversity, and transfer capacity of ARG-carrying plasmids in Gram-positive bacteria, and more specifically in lactic acid bacteria (LAB; the majority microbial types in cheese), has been left largely unexplored. The plasmid complement of most LAB species is complex, making the detection of associations between plasmids and antibiotic resistance challenging and laborious $[27,28]$, and certainly, high-throughput sequencing and assembly technologies have so far failed to associate antibiotic resistance genes with plasmids in genomic and metagenomics studies [29]. In this context, this work reports a simple method for isolating functional plasmids that confer antibiotic resistance to LAB species. The results provide knowledge on the prevalence and diversity of plasmids conferring tetracycline and erythromycin resistance to cheese bacteria, and provide preliminary insight into the role of plasmids in the spread of antibiotic resistance throughout dairy ecosystems.

\section{Results}

\subsection{Diversity of Plasmid Profiles}

Counts of resistant aerobic mesophilic bacteria and LAB were performed on Plate Count Milk (PCM) and de Man, Rogosa, and Sharpe (MRS) agar plates, respectively, both supplemented with tetracycline or erythromycin, from samples of Cabrales cheese at day 3 (3D; early manufacture) and day 60 (60D; end of ripening). Large counts of tetracyclineand erythromycin-resistant bacteria were enumerated in all samples analyzed; these were almost identical at the same sampling point. The values obtained in PCM plates ranged from $10^{8}$ to $10^{6} \mathrm{ufc} \mathrm{mL}^{-1}$ at day 3 and 60 , respectively. However, the level of resistant bacteria in MRS plates were lower than in PCM plates, since in the former were observed values from $10^{5}$ ufc $\mathrm{mL}^{-1}$ during manufacture and $10^{6} \mathrm{ufc} \mathrm{mL}^{-1}$ at the end of ripening. Total plasmid DNA was isolated from semiconfluent colonies of total aerobic mesophilic bacteria (PCM-3D and PCM-60D) and LAB (MRS-3D and MRS-60D) grown in the counting plates. For a better comparison of the diversity, total plasmid DNA was initially digested using restriction enzymes before visualization by gel electrophoresis. Complex patterns of intense and weak plasmid bands were observed for all samples. Figure S1 shows an example of the PstI and XhoI digestion patterns for the total plasmid DNA recovered from the different samples. Although the digestion profiles obtained on PCM and MRS at 3D sample look rather different, the number, intensity and size of the bands were similar at 60D sample.

\subsection{Screening of Plasmids Providing Antibiotic Resistance}

Plasmid DNA from the PCM-3D, PCM-60D, MRS-3D and MRS-60D samples was independently transformed into electrocompetent cells of Lactococcus lactis NZ9000, Lactiplantibacillus plantarum NC8, and Lacticaseibacillus casei LB23. Tetracycline- and erythromycinresistant transformants were then selected on GM17 and MRS solid media supplemented with the required antibiotic. Overall, 54 tetracycline-resistant colonies of lactococci were obtained with the plasmid DNA from the PCM-3D (30 colonies) and MRS-3D plates 
(24 colonies), while 13 resistant colonies were obtained using plasmid DNA from the PCM60D (8 colonies) and MRS-60D plates (5 colonies). Similarly, 10 and 15 tetracycline-resistant colonies of L. casei and L. plantarum, respectively, were found; these were all obtained with plasmid DNA from the PCM-3D sample. Finally, only five erythromycin-resistant colonies were recovered; these were obtained in L. lactis when using again plasmid DNA from the PCM-3D sample.

All resistant transformants were grown overnight in liquid media with antibiotics and analyzed for the presence of plasmid DNA; after extraction and purification, plasmids were detected in all 97 resistant colonies. Restriction analysis of plasmid DNA identified seven digestion profiles among the tetracycline-resistant transformants, five among the L. lactis, one each for the two Lactobacillus strains, and a single digestion profile among the erythromycin-resistant L. lactis cells (Figure 1). This suggested the presence of an equivalent number of different plasmid molecules, designated pTC1 to pTC7 for those providing tetracycline resistance, and pERM1 for that providing erythromycin resistance. pTC1 was the most widespread plasmid (found in 49 out of 92 tetracycline-resistant colonies). It was recovered in L. lactis with plasmid DNA from all four tetracycline-grown bacteria samples. The plasmid profile of pTC1 was the only one observed from the PCM-3D, PCM-60D and MRS-60D samples. In addition, unique plasmid digestion profiles were also detected among erythromycin-resistant colonies in lactococci (pERM1) and tetracycline-resistance colonies in lactobacilli strains (pTC6 in L. casei and pTC7 in L. plantarum). In contrast, five different plasmid profiles were obtained in Lactococcus with plasmid DNA from the MRS3D sample. These were detected with variable frequency among the colonies analyzed: pTC1 (in 6 colonies), pTC2 (in 3), pTC3 (in 1), pTC4 (in 2), and pTC5 (in 12). The estimated size of the plasmids ranged from about 4 (pTC6) to 50 (pEMR1) kbp.

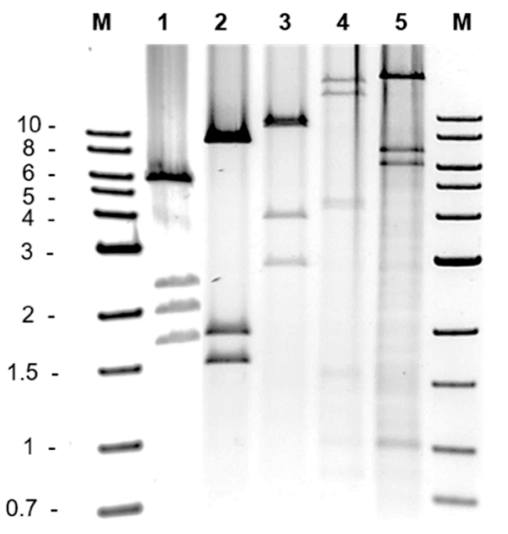

(a)

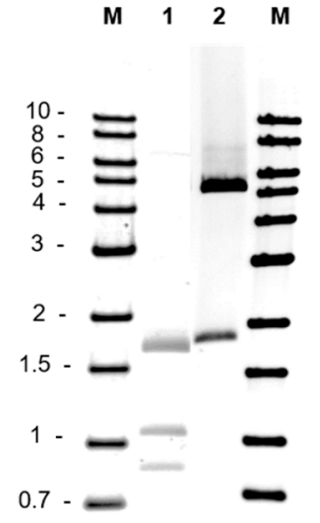

(b)

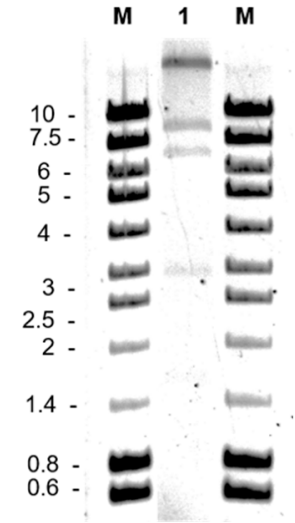

(c)

Figure 1. Restriction profiles of plasmid DNA obtained from transformants of tetracycline-resistant Lactococcus lactis NZ9000 (a), tetracycline-resistant Lacticaseibacillus casei BL23 and Lactiplantibacillus plantarum NC8 (b), and erythromycin-resistant L. lactis NZ9000 (c). Order: Panel (a), lanes 1 through 5, pTC1 to pTC5 digested with EcoRI; Panel (b), lanes 1 and 2, pTC6, and pTC7 digested with HindIII; Panel (c), lane 1, pERM1 digested with PvuI and EcoRI. M, Molecular weight markers.

\subsection{Antibiotic Susceptibility of Plasmid-Harboring Transformants}

Transformant strains carrying the plasmids from pTC1 to pTC7 and pERM1 (representative plasmids of all different profiles) were tested for antibiotic susceptibility against a set of 16 antibiotics using a broth microdilution method (Sensititre) and the evaluator strip (MICE) system and the results compared to those for the untransformed parental strains. The results obtained are summarized in Table 1. L. lactis cells carrying tetracycline resistance plasmids showed a MIC for this antibiotic of $128-192 \mu \mathrm{g} \mathrm{mL}^{-1}$ compared to $1 \mu \mathrm{g} \mathrm{mL}^{-1}$ of the host strain L. lactis NZ9000. Transformants harboring pTC3 and pTC5 also showed increased MICs to streptomycin (32-64 versus $16 \mu \mathrm{g} \mathrm{mL} \mathrm{m}^{-1}$ ) and chloramphenicol (16-32 versus $4 \mu \mathrm{g} \mathrm{mL}^{-1}$ ). The presence of plasmids in L. casei and L. plantarum 
moderately increased the MIC to tetracycline, while MIC values for other antibiotics were unaffected (Table 1). Finally, the erythromycin-resistant L. lactis transformants showed a MIC of erythromycin $>256 \mu \mathrm{g} \mathrm{mL}^{-1}$. Additionally, they showed increased MICs of streptomycin $\left(>256 \mu \mathrm{g} \mathrm{mL}^{-1}\right)$, neomycin $\left(32 \mu \mathrm{g} \mathrm{mL}^{-1}\right)$, tetracycline $\left(>256 \mu \mathrm{g} \mathrm{mL}^{-1}\right)$, clindamycin $\left(>256 \mu \mathrm{g} \mathrm{mL}^{-1}\right)$, and quinupristin-dalfopristin $\left(>8 \mu \mathrm{g} \mathrm{mL}^{-1}\right)$ (Table 1).

Table 1. Minimum inhibitory concentration (MIC) of 16 antibiotics to the plasmid-free Lactococcus lactis NZ9000, Lacticaseibacillus casei LB23, and Lactiplantibacillus plantarum NC8 and their plasmid-containing transformed derivatives.

\begin{tabular}{|c|c|c|c|c|c|c|c|c|c|c|c|c|c|c|c|c|}
\hline \multirow{2}{*}{ Species/Strain } & \multicolumn{16}{|c|}{ Minimum Inhibitory Concentration $\left(\mu \mathrm{g} \mathrm{mL}^{-1}\right)$} \\
\hline & $\mathrm{Gm}$ & $\mathrm{Km}$ & Sm & $\mathrm{Nm}$ & Tc & Em & $\mathrm{Cl}$ & $\mathrm{Cm}$ & Am & Pc & Va & Q-da & $\mathbf{L z}$ & $\mathrm{Tm}$ & $\mathbf{C i}$ & Rif \\
\hline $\begin{array}{c}\text { Lactococcus lactis } \\
\text { NZ9000 }\end{array}$ & 1 & 4 & 16 & 4 & 1 & 0.12 & 0.12 & 4 & 0.25 & 0.5 & 0.5 & 4 & 2 & $>64$ & 16 & 64 \\
\hline L. lactis pTC1 & 1 & 4 & 16 & 4 & 128 & 0.06 & 0.12 & 4 & 0.25 & 0.25 & 0.25 & 4 & 2 & $>64$ & 16 & 32 \\
\hline L. lactis pTC2 & 0.5 & 4 & 16 & 2 & 128 & 0.06 & 0.06 & 4 & 0.25 & 0.25 & 0.5 & 4 & 2 & $>64$ & 16 & 32 \\
\hline L. lactis $\mathrm{pTC} 3$ & 0.5 & 4 & 64 & 2 & 128 & 0.06 & 0.12 & 32 & 0.25 & 0.25 & 0.5 & 4 & 1 & $>64$ & 16 & 64 \\
\hline L. lactis pTC4 & 1 & 4 & 16 & 4 & 128 & 0.06 & 0.12 & 4 & 0.25 & 0.25 & 0.25 & 4 & 2 & $>64$ & 16 & 32 \\
\hline L. lactis pTC5 & 1 & 4 & 32 & 2 & 192 & 0.12 & 0.12 & 16 & 0.25 & 0.25 & 0.5 & 4 & 2 & $>64$ & 16 & 64 \\
\hline L. lactis pEMR1 & 1 & 4 & $>256$ & 32 & $>256$ & $>256$ & $>256$ & 8 & 0.25 & 0.25 & 0.5 & $>8$ & 2 & $>64$ & 16 & 64 \\
\hline $\begin{array}{c}\text { Lacticaseibacillus } \\
\text { casei BL23 }\end{array}$ & 2 & 16 & 8 & 4 & 2 & 0.06 & 0.03 & 4 & 1 & 0.5 & $>128$ & 0.5 & 1 & 1 & 1 & 0.12 \\
\hline L. casei pTC6 & 1 & 32 & 16 & 2 & 32 & 0.25 & 0.06 & 8 & 0.5 & 1 & $>128$ & 2 & 4 & 0.5 & 32 & 8 \\
\hline $\begin{array}{c}\text { Lactiplantibacillus } \\
\text { plantarum NC8 }\end{array}$ & 0.5 & 16 & 32 & 1 & 32 & 0.12 & 1 & 8 & 0.25 & 2 & $>128$ & 2 & 4 & 8 & 32 & 2 \\
\hline L. plantarum pTC7 & 0.5 & 16 & 16 & 0.5 & 64 & 0.25 & 1 & 8 & 0.25 & 2 & $>128$ & 1 & 4 & 16 & 64 & 2 \\
\hline
\end{tabular}

Key of antibiotics: $\mathrm{Gm}$, gentamicin; Km, kanamycin; Sm, streptomycin; $\mathrm{Nm}$, neomycin; Tc, tetracycline; Em, erythromycin; $\mathrm{Cl}$, clindamycin; $\mathrm{Cm}$, chloramphenicol; Am, ampicillin; Pc, penicillin G; Va, vancomycin; Q-da, quinupristin-dalfopristin; Lz, linezolid; Tm, trimethoprim; $\mathrm{Ci}$, ciprofloxacin; Rif, rifampicin. Grey-shaded boxes highlight the plasmid-associated increased MICs obtained in the transformants.

\subsection{Detection of Tetracycline and Erythromycin Resistance Genes}

The presence of tetracycline and erythromycin resistance genes in the plasmids responsible for the increased MICs to these antibiotics in host strains was initially evaluated by conventional PCR. Genes coding for ribosomal protection proteins conferring tetracycline resistance were amplified by PCR using the universal pair of primers DI-DII, and plasmid DNA from the tetracycline-resistant $L$. lactis transformants as a template. Subsequent gene-specific PCR analysis for the tetracycline resistance genes tet $(\mathrm{W})$, tet $(\mathrm{M})$, tet $(\mathrm{S})$, tet $(\mathrm{O})$, tet $(\mathrm{K})$, and tet $(\mathrm{L})$ showed positive amplification only when targeting tet $(\mathrm{S})$ gene. This result was further confirmed by sequencing of the amplicons. Surprisingly, no amplification was ever obtained when DNA of the tetracycline-resistant lactobacilli transformants was used as a template. While the presence of several genes conferring erythromycin resistance (ermA, ermB, erm $C, e r m F$, and $m e f A$ ) were assessed, positive amplification was just obtained when using gene-specific primers for ermB and plasmid DNA from erythromycin-resistant L. lactis as a template. This gene codes for a methyltransferase which confers resistance to macrolides, lincosamides and streptogramins (the MLS phenotype), which might thus explain the high MIC value for clindamycin.

\subsection{Sequencing, Assembly and Annotation of Plasmids}

Representative plasmids of the different digestion patterns were selected for entire sequencing. High quality reads were assembled, annotated, and analyzed. After assembly, a single plasmid molecule was detected for all antibiotic-resistant plasmid patterns except for that of pTC6, the profile of which consisted of two plasmid molecules (pTC6.1 and pTC6.2). The overall G+C content of the plasmids ranged from $30.6 \%$ to $34.3 \%$ for those recovered in L. lactis, and from $34.3 \%$ to $39.5 \%$ for those in lactobacilli species. Table S1 shows the ORFs identified in each of the plasmids and the putative biological function of their deduced proteins. The majority of ORFs showed high homology with genes located on the plasmids or the chromosome of the Lactococcus species. However, some ORFs showed 
homology to genes found in other Lactobacillales species, such as Streptococcus parauberis, Enterococcus faecalis, Enterococcus faecium, etc. Further, a minority of the deduced amino acid sequences shared homology with proteins from Listeria monocytogenes, Staphylococcus aureus, and Bacillus licheniformis, such as (respectively) an ATP-dependent helicase (pTC4-ORF23 and pTC5-ORF22; Table S1), a replication initiation factor domain-containing protein (pTC5ORF 30; Table S1), and a hypothetical protein (pTC1-ORF12; Table S1). Additionally, a region of pERM1 encompassing ORF3, ORF4 and ORF5 showed homology (respectively) to genes from Tissierella pigra, Halanaerobiaceae bacterium and Alkalibaculum bacchi.

\subsection{Tetracycline Resistance Plasmids}

Nucleotide sequence analysis identified two modules in pTC1. The first covered $88 \%$ of the molecule and proved to be very similar ( $98 \%$ nucleotide identity) to a plasmid region of S. parauberis SPOF3K (CP025421.1), which also harbors a Tet(S)-encoding gene. Besides tet $(\mathrm{S})$, this module accommodates genes coding for two replication proteins of the RepB family, and four ORFs encoding proteins involved in conjugation and mobilization (Figure 2; Table S1). The second module showed high homology ( $98 \%$ nucleotide identity) to segments of plasmids such as, among others, pLd10 (MG813924.1), pUL8B (CP016705.1) and pAH82 (AF243383.1) of L. lactis subsp. lactis, and pNZ4000 (AF036485.2) and pJM3A (CP016737.1) of L. lactis subsp. cremoris.

A major part of pTC2 ( $\triangle \mathrm{ORF} 2$ to ORF11) was identical to the first module of pTC1; this includes the tet( $\mathrm{S})$ gene and the region encoding replication and mobilization functions. The pTC1 and pTC2 are of about the same size and differ only in a few genes encoding putative recombinases and hypothetical proteins (Figure 2; Table S1).

pTC3 was organized into three different modules. The whole plasmid shares (with minor rearrangements) high homology with the entire sequence of the lactococcal plasmids p158F (CP016690.1) and pHP003 (AF247159.1). Beyond tet(S), the plasmid contained genes associated with chloramphenicol (cat; ORF26) and streptomycin (str; ORF31) resistance. The region containing the three antibiotic resistance genes is highly homologous to a segment flanked by two IS6-like transposases of pK214 (X92946.1). pTC3 also contained ORFs encoding three complete and two partial replication proteins of the RepB and RepC families and eight proteins associated with mobilization (Figure 2; Table S1).

At $42,318 \mathrm{bp}$, pTC4 was the largest plasmid recovered from the tetracycline-resistant transformants. Structurally, it was organized as an apparent mosaic resulting from the fusion of segments of a variety of L. lactis plasmids, including fragments from pK214, pS127 (CP061323.1), p001F (CP053672.2), pLP712 (FJ649478.1), pC41 (AP018500.1), and pA12-4 (LT599053.1). Some regions of pTC4 showed strong identity to others from plasmids of Lactococcus garvieae (pNUF18; LC316979), Macrococcus cannis (pKM0218; MF477836.1), S. aureus (plasmid I; LT799381.1), Carnobacterium divergens (pMFPA43A1505B; LT984412.1), and E. faecium (e.g., pV24-4 [CP036155.1] and pA6521_3 [CP061820.1]). This agrees well with the presence of seven IS-like elements in the pTC4 molecule (Figure 2; Table S1). Two such IS flanked the region harboring tet(S). Among other accessory genes, ORFs coding for the synthesis and secretion of a bacteriocin of the lactococcin family were also noted (Table S1).

Much of the pTC5 sequence (77\%), including its tet(S)-associated gene, was shown to be almost identical (99\%) to that of pTC4. The differential region in pTC5 (from ORF26 to ORF37) was flanked by two transposases and comprised genes involved in resistance to streptomycin and chloramphenicol (Figure 2; Table S1). This antibiotic resistance-dedicated region was very similar to a section of pTC3. 

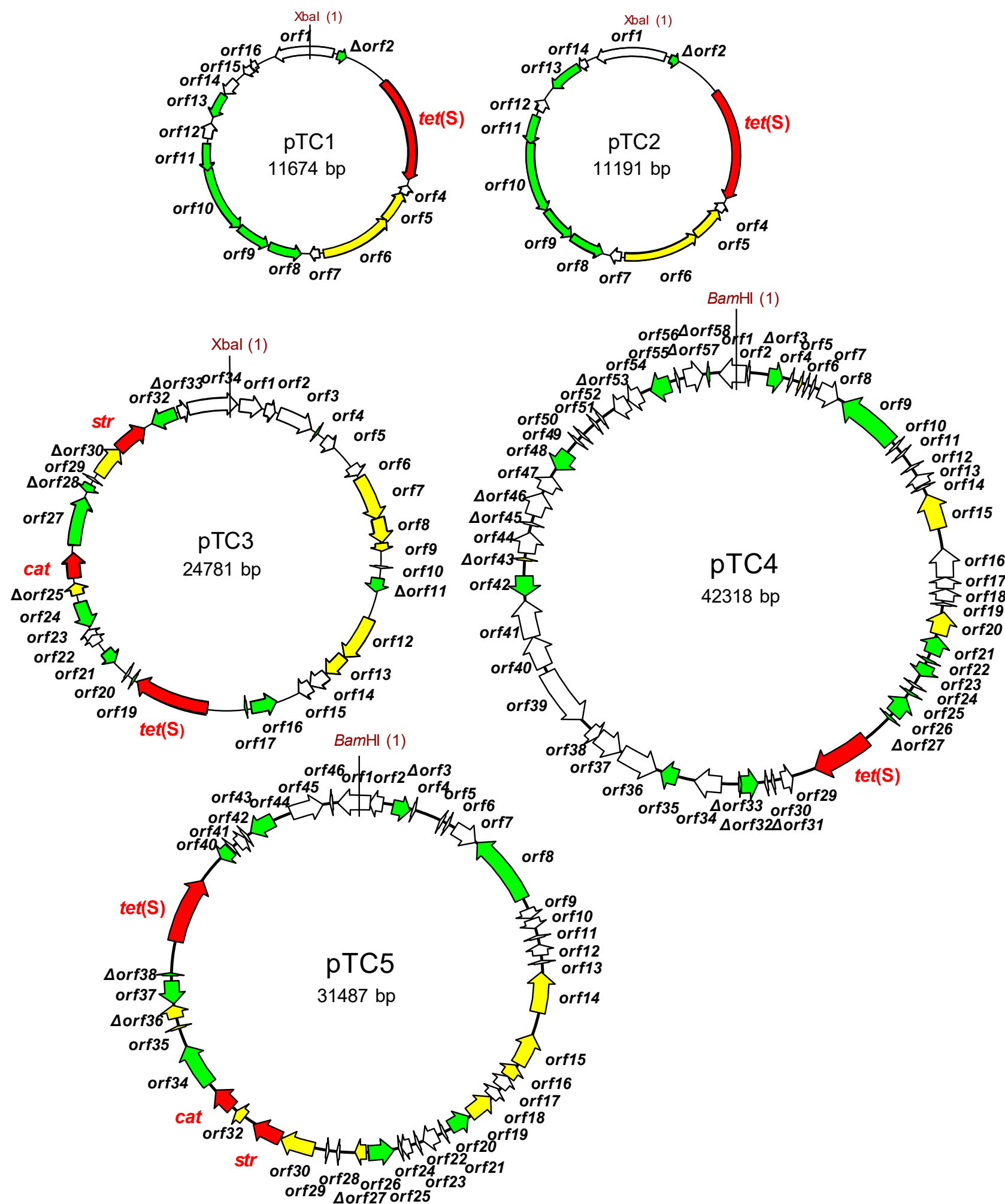

Figure 2. Drawn to scale genetic maps of the tetracycline resistance plasmids recovered in Lactococcus lactis, pTC1 through pTC5. Arrows indicate the position, direction and length of the open reading frames (ORFs) identified. The position of tet(S), str and cat genes are highlighted in red. Color code of the ORFs: red, antibiotic resistance genes; yellow, genes involved in replication; green, insertion sequences and genes involved in mobilization; white, genes encoding other or unknown functions. 
pTC6.1 and pTC6.2 showed 100\% nucleotide identity to, respectively, pWCFS101 (CR377165.1) and pWCFS102 (CR377164.1) from L. plantarum WCFS1. These plasmids replicate by a rolling circle mechanism, in agreement with their respective prototypes, pC194 and pMV158, to which they bear homology. Apart from genes coding for replication-associated proteins, only ORFs coding for hypothetical proteins were detected. No tetracycline resistance determinants were identified (Figure 3, Table S1).
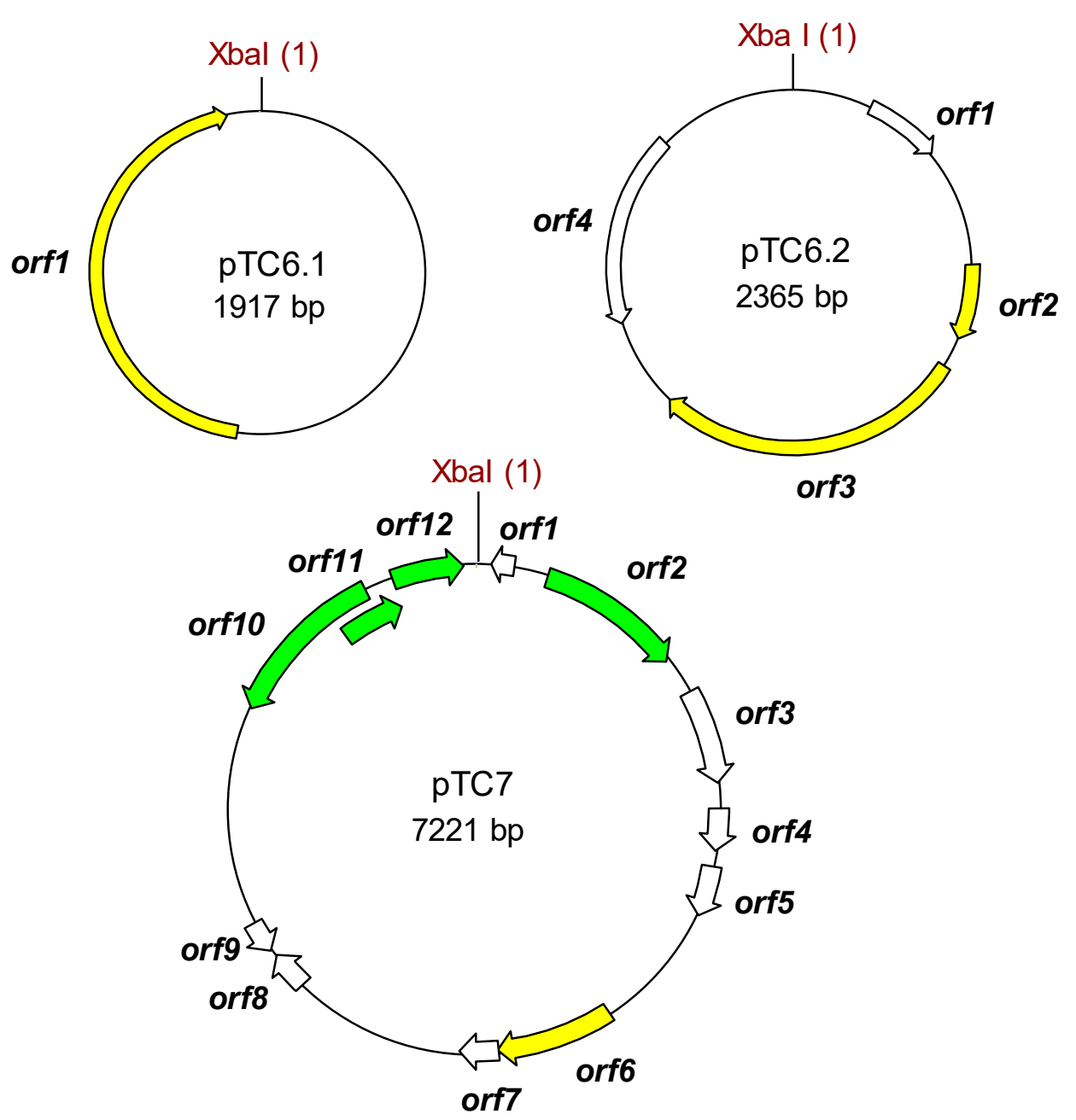

Figure 3. Drawn to scale genetic maps of the tetracycline resistance plasmids recovered in Lacticaseibacillus casei (pTC6.1, pTC6.2) and Lactiplantibacillus plantarum (pTC7). Plasmid features as in Figure 2.

Finally, the sequence of pTC7 showed only a five-nucleotide difference to that of plasmid p256 from L. plantarum DSM 20174 (AJ62894.1). It is worth noting the presence in pTC7 of ORFs encoding proteins involved in plasmid maintenance (ORF12 and ORF13), but not in replication initiation functions. Again as in pTC6.1 and pTC6.2, ORFs coding for dedicated proteins involved in tetracycline resistance were absent in pTC7 (Figure 3; Table S1).

\subsection{Erythromycin Resistance Plasmids}

pERM1, the single plasmid recovered from the erythromycin-resistant L. lactis transformants, was organized into several modules bound by IS elements (Figure 4; Table $\mathrm{S1}$ ). Besides ermB, a functional tet(S) was also identified in the pERM1 sequence. The module encoding ermB (ORF33) and tet(S) (ORF29) genes showed strong nucleotide homology to a conserved set of structures identified in the chromosome of Mammaliicoccus sciuri GDK8D6P (CP065792.1) and Streptococcus dysgalactiae NTUH_1743 (EF682209.1), as 
well as in plasmids of Macrococcus canis (pKM0218; MF477836.1), Lactococcus raffinolactis (pLraf_19_4S_1; CP050535.1), C. divergens (pMFPA43A1405B; LT984412.1), and L. lactis (pUC08B; CP016727.1). In contrast, the module harboring other resistance genes, namely streptomycin (str), quinupristin-dalfopristin $(V g b)$, tunicamycin $(\operatorname{tmr} B)$, and aminoglycosides (ant [6]-Ia and vat), showed no significant homology with sequences deposited in the NCBI database. The remaining modules, which include ORFs coding for proteins involved in replication and conjugal transfer, proved to be identical to others from pS127 (CP061323.1) and pMRC01 (AE001272.1) in L. lactis.

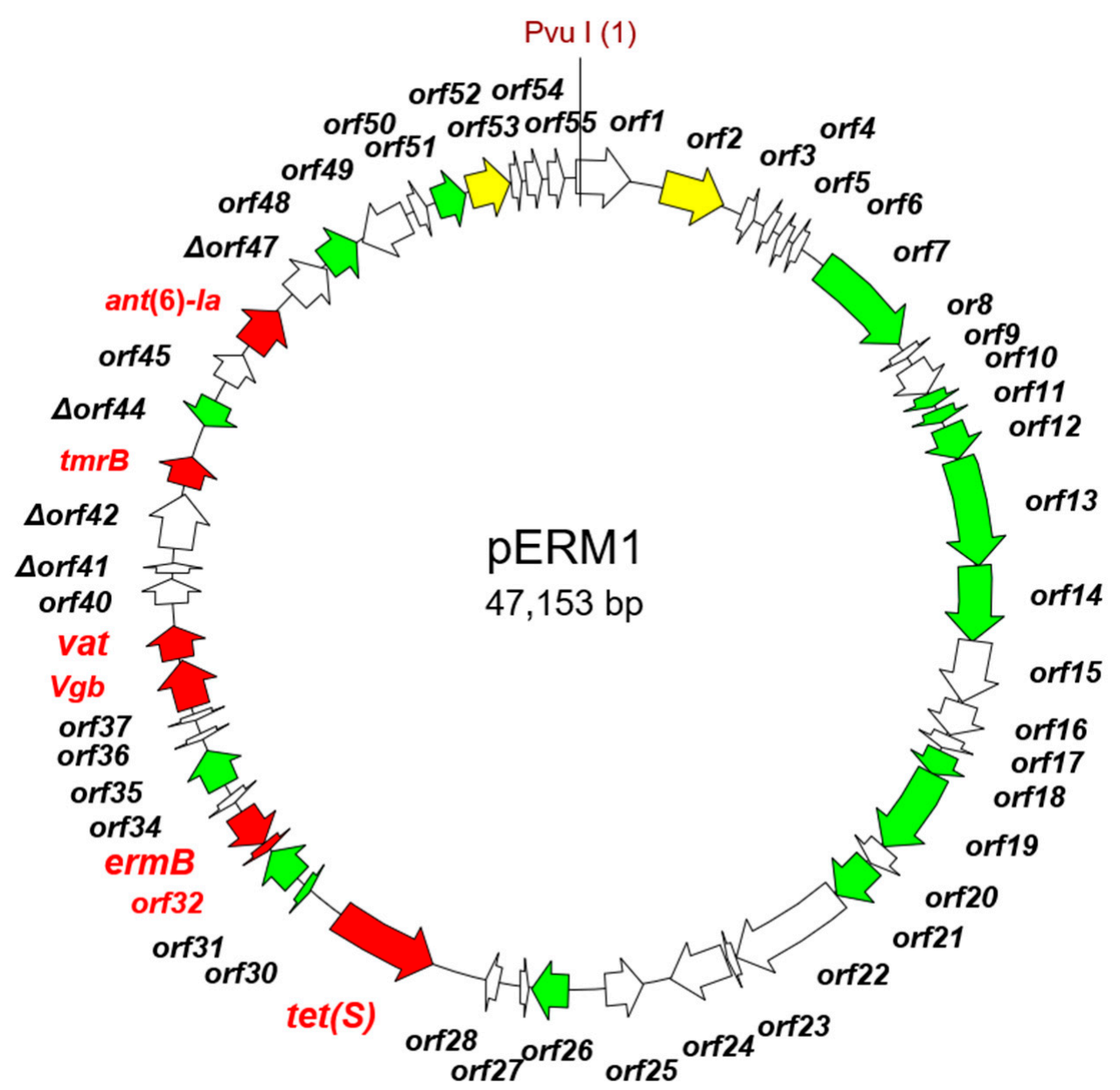

Figure 4. Genetic map of the erythromycin resistance plasmid pERM1 recovered in Lactococcus lactis. The position of ermB and other antibiotic resistance genes are highlighted in red. Plasmid features as in Figure 2.

\subsection{Nucleotide Sequence of tet(S) and Its Flanking Regions}

All six plasmids carrying the tet(S) gene (pTC1 to pTC5 and pERM1) shared an identical block of $3062 \mathrm{bp}$ (Figure 5). This core region started $988 \mathrm{bp}$ upstream of the ATG position of tet(S) and ended $133 \mathrm{bp}$ downstream of its stop codon. Within these blocks, a single nucleotide transversion (C to A) in the sequence of pTC1 was noted, and a single nucleotide transition (C to T) in pERM1 (Figure 5). The tet(S) gene contains 1941 nucleotides with the capacity to encode a protein 646 amino acids long; the Tet(S) protein coded by all these plasmids was identical. 
$1 \mathrm{bp}$

I

CTCTGAGTTGGTGAATCCAATTATTCAGAAGAAAGAGAAACAGTATCTAGTAAAAATAGCCGTTCGATA

TTTAGACAATGAAACAAAGATTGAAAATATTTCCCAATACCAATTAACTTTAGAGAAGAAGGATAACTG

GAAAATAATAATGAATGAATAAAGATATTAAGATGAAACAATACTTGATATTTAGTATAAGCAAAAA

AAATTGTATGTCACTATAGCAAACTTATAATGATTTAGCATAAATAATCCAAAATATAGCGTGAAATCAAC DR $\overline{3}-\cdots$

CTTC/ATATGAGAAGTATAAGCAAATTCACCTTTATTCTAACTTATAACTATTTTCATTACATTACTTAAAAA

GGTCTCTCCAATTTTTTCCAAATAAACAGTATAACTTTTAATGATATTTTCCAAGTCAAACTTAATATTAAC

AATTCAAAACTATTGGAACCACTGCAAAATATTTTGTTAAGCAGTATATATTTCAAAAATTATACGTAATAT

ATTTGTAGAAAGGTTGTGGACAGTTGTCCTATTGACCTGAAAATAATATAATAGCTGGATGAATAA AATCCCTTATGAACTTGTAAATCGTTATTAAATCGCTGAATTTTGATAGCCATTCTGAAGAGTTATCTTCA

ACTACTACACTAACTTCCATTAATTTCTCATIAATITCCCTTTCGTTCAAAAAATATGGTTGGCITTACAAG CATTCTATCATATGATAGAATTAAGATAAC/TATTCAAAAGGAGATAATAAAATGGGGCAAGGTATTCTT AAATAAACTGTCAATTAGATAGCGGGAATAATTAATTAAGCATCCTTATLTIAAATAAGGACTGGTTTTTT GTGCCCAGTTTAAGAATACTTTIATCATTTTATCATAAAGCATCTGTGGCTATCAGTGTGTAGTATACAGC

TATTTTTGTATTAAAATCCCAGTGATAAgagtatTTATCACTGGGATTTTTTCTGCTTTTTGAGCTTTT,

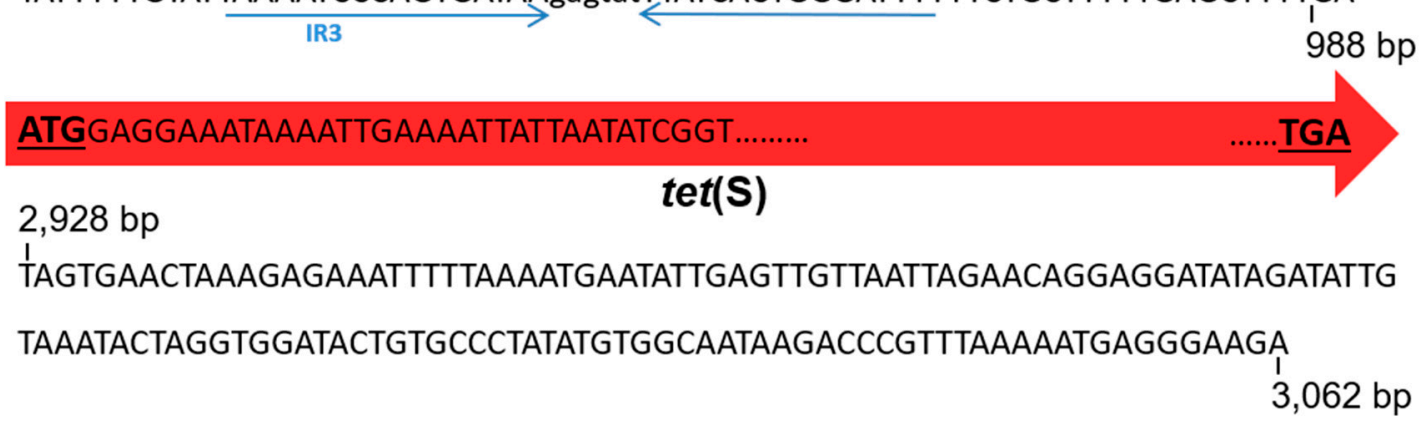

Figure 5. Conserved DNA sequence of the tet(S) gene and its surrounding regions in all resistance plasmids retrieved in L. lactis NZ9000. The red arrow represents the whole tet(S) gene from the start to the stop codons (in bold and underlined). Direct (DR) and inverted (IR) repeats upstream of tet(S) are underlined by solid pale-blue and dotted-red arrows, respectively. Putative -35 and -10 positions of promoter and ribosome binding site sequences are in bold and underlined. Colored in green, single nucleotide polymorphisms detected, respectively, in pTC1 $(\mathrm{C} \rightarrow \mathrm{A})$ and pEMR1 $(\mathrm{C} \rightarrow \mathrm{T})$.

\section{Discussion}

Plasmids enable bacteria to recruit accessory traits, including resistance to antibiotics, that confer selective advantages in terms of colonization, development or persistence in different environments [10]. Plasmids, and thus resistances, can be spread via horizontal gene transfer events such as conjugation and mobilization to neighboring partners, causing real risks to human health if they reach pathogenic or opportunistic bacteria [30]. The presence of antibiotic resistance determinants in plasmids carried by food-associated bacteria are thought to pose the greatest risk of resistance spreading along the food chain [17].

Resistant strains and resistance genes can be detected via phenotypic and genetic surveys, respectively [31,32]. Some resistance genes have been identified and located to plasmids [24], and even isolated and characterized [33,34]. However, the assignment of resistances to plasmids can be challenging and laborious, requiring studies on transference and mobilization by conjugation [26,35-37], hybridization analysis [24,36,38], and the location of resistance genes by analysing assembled plasmids sequences [39-41]. Furthermore, currently-in-use high-throughput sequencing and assembly technologies have failed to associate antibiotic resistance genes with plasmids in genomic and metagenomics stud- 
ies [29]. The present work, however, reports a simple method of retrieving plasmids able to replicate in specific hosts and capable of conferring resistance to a particular antibiotic. These plasmids can then be fully characterized at the phenotypic and genetic levels.

Although ARG-carrying plasmids might be extracted and purified from bacteria as they are naturally found in cheese, the present work involved preliminary enrichment with antibiotics to provide proof of concept. Tetracycline and erythromycin were selected due to their extensive use as therapeutic agents and as growth promoters in Europe until banned in 2006 [42]. Further, resistance to these two antibiotics has already spread in dairy environments [21,43] and certainly among LAB species [44,45].

Overall, five plasmids replicating in L. lactis ranging in size from 11 to $42 \mathrm{~kb}$ were found to confer resistance to tetracycline. Although tet $(\mathrm{S})$, tet $(\mathrm{M}), \operatorname{tet}(\mathrm{O}), \operatorname{tet}(\mathrm{W}), \operatorname{tet}(\mathrm{L})$, and $\operatorname{tet}(\mathrm{K})$ have previously been detected in dairy LAB $[21,22,43,46]$, only tet(S) was detected in the tetracycline-resistant plasmids characterized in the present study. In a previous functional metagenomics study, $\operatorname{tet}(\mathrm{A}), \operatorname{tet}(\mathrm{M}), \operatorname{tet}(\mathrm{S})$ and $\operatorname{tet}(\mathrm{L})$ were found throughout Cabrales manufacture and ripening [22]. The presence of distinct tetracycline resistance genes in different cheese batches can be explained by the great heterogeneity of the microbial populations in cheeses made from raw-milk. A larger copy number of the plasmids carrying tet $(\mathrm{S})$ - a possibility not assessed in the present study - might help mask other tetracycline resistance genes. Despite finding only tet(S), at least five different $L$. lactis plasmids carrying the gene were detected, suggesting the wide spread of tet(S) across lactococcal plasmids. In contrast, a single plasmid encoding erythromycin resistance was retrieved in the same species, which suggests ermB to be less abundant than tet(S) in cheese.

Sequence analysis revealed the presence of RepB family proteins in all L. lactis plasmids, suggesting they follow a theta-type replication mechanism [47], their replicons belonging to different theta-replicating plasmid families. Although no genes encoding replication proteins were detected in pTC7 from L. plantarum, a theta-type mode of replication has been proposed for its closest relative, p256 [48]. Plasmids with such a mode of replication are more stable than those that use the rolling circle mechanism. Further, large numbers of theta-replicating plasmids can coexist in a single cell [28,49-51], which agrees well with the high prevalence of these replicons in cheese bacteria. Nevertheless, theta-replicating plasmids have a narrow host range, sometimes a single species or a few of close relative species [52]. In agreement with this, in this work, the same plasmid DNA pool was electroporated into three species, but plasmids carrying dedicated resistance genes were only recovered from L. lactis, the species that allows replication. The same plasmids, and thus the same resistance genes, were retrieved from samples on day 3 and day 60 , even though the bacterial populations and their associated resistances were different, see [22,53]. The likely existence of resistance plasmids in other cheese-borne bacteria demands other types of bacterial species be used as a host, including Enterococcus spp., Staphylococcus spp., Streptococcus spp., and Escherichia coli, all of which have been reported important in the spread of antibiotic resistance in cheese [22,53-56].

Numerous IS- and transposase-related sequences were identified delimitating the different modules of the plasmids, or even flanking distinct functional blocks within the modules. A mosaic plasmid structure bound by IS has been recognized as paramount for maintaining the plasticity necessary for LAB to adapt to the dairy environment $[57,58]$. This type of structure may help alleviate the energetic costs of hosting large plasmids and complex extrachromosomal elements $[59,60]$. The modular structure argues in favor of a common pool of exchangeable blocks, which could offer bacteria a changing plasmid complement, even under similar genetic backgrounds [61]. In this respect, the blocks harboring tet(S) proved to be almost identical to regions of the S. parauberis plasmid SPOF3 [62] and of pK214 from L. lactis K214 [63]. Indeed, the block harboring the chloramphenicol and streptomycin resistance genes was identical to a region of pK214 [63]. Similarly, the block encoding ermB was very similar to another in $M$. canis pKM0218 [64]. The surrounding regions of tet(S) were also identical in pTC1 through pTC5 and pERM1, which strongly suggests a recent horizontal transfer from a common source. The presence of such blocks 
in different plasmids, and in plasmids from different species and genera, further suggests that these blocks are the real spreadable elements, with plasmids the preferred host in L. lactis $[2,9,11,28,58]$.

Increased MICs for some antibiotics have largely been attributed to non-specific mechanisms such as reduced antibiotic uptake, reduced cell permeability, the thickness and compactness of the cell wall, defective cell wall autolytic systems, and the presence of multidrug resistance transporters $[65,66]$. Although none of the proteins encoded by ORFs from pTC6.1-pTC6.2, or pTC7 could be assigned any of these functions, it cannot be ruled out that the moderate tetracycline resistance provided to L. case $i$ and L. plantarum is associated with one or more of the above mechanisms.

Selection for tetracycline and erythromycin resistance was pursued, but genes conferring resistance to other antibiotics were also identified, namely streptomycin, quinupristindalfopristin, tunicamycin, chloramphenicol, and aminoglycosides. These genes, either on plasmids or in the chromosome, have been repeatedly detected in LAB species and strains $[23,63,67,68]$. Linkage in the same chloramphenicol and streptomycin resistance cluster might allow co-selection to explain the maintenance of resistance to these antibiotics, and possibly to others [69]. The linkage and ensuing co-selection of antibiotic resistance and adaptive biological functions has been hypothesized by many authors [59,70-73]. However, in the present work, no feature that would help LAB develop and compete in the milk environment (lactose utilization, proteinase activity, phage resistance, etc.) was envisioned in any of the resistance plasmids. The maintenance and transfer of resistance plasmids in the dairy environment appears, thus, to be promoted by the presence of antibiotic residues in milk [74-76], although it might also be explained by plasmid-encoded addictive mechanisms [77] or host chromosomal adaptations reducing any associated biological costs, resulting in no selection against a plasmid's loss [58,78,79].

\section{Materials and Methods}

\subsection{Lactic Acid Bacteria Strains and Culture Conditions}

L. lactis NZ9000 was grown under aerobic conditions in M17 medium (Biokar, Beauvais, France) supplemented with $1 \%$ glucose (GM17) at $32{ }^{\circ} \mathrm{C}$ for $24-48 \mathrm{~h}$. L. plantarum NC8 and L. casei BL23 were cultured in de Man, Rogosa, Sharpe medium (MRS) (Merck, Darmstadt, Germany) at $32{ }^{\circ} \mathrm{C}$ for $24-48 \mathrm{~h}$. Agar plates were obtained by supplementing the respective broth media with $2 \%$ agar (Merk).

\subsection{Cheese Sampling}

Samples of Cabrales cheese were taken during the manufacturing (3 days) and ripening (60 days) stages of production, homogenized in a Stomacher (Seward, Worthing, UK) with $2 \%(w / v)$ sodium citrate (Merck), and serially diluted in Ringer's solution (Merck). Aerobic mesophilic bacteria and LAB resistant to tetracycline and erythromycin were enumerated by plating the dilutions on Plate Count Milk (PCM; Merck) and MRS agar, respectively, supplemented with tetracycline $\left(25 \mu \mathrm{g} \mathrm{mL}{ }^{-1}\right)$ or erythromycin $\left(25 \mu \mathrm{g} \mathrm{mL}^{-1}\right)$ (both from Merck). Plates were incubated at $32{ }^{\circ} \mathrm{C}(\mathrm{PCM})$ or $37^{\circ} \mathrm{C}$ (MRS) for $48 \mathrm{~h}$. Colonies showing semi-confluent growth were harvested, suspended in Brain Heart Infusion (BHI) broth (Merck) without antibiotics, supplemented with $25 \%$ glycerol, and stored at $-80^{\circ} \mathrm{C}$.

\subsection{Plasmid Isolation and Transformation}

Plasmid DNA from antibiotic-resistant bacteria was extracted from $200 \mu \mathrm{L}$ of their frozen cell suspensions. These suspensions were first centrifuged, washed with sterile phosphate-buffered saline (PBS; Merck), and then suspended in $200 \mu \mathrm{L}$ of the suspension buffer supplied with the High Pure Plasmid Isolation Kit (Roche, Basel, Switzerland). Lysozyme (20 mg mL $\left.{ }^{-1}\right)$, mutanolysin $(20 \mathrm{U})$ and lysostaphin $\left(50 \mu \mathrm{g} \mathrm{mL}^{-1}\right)$ (all from SigmaAldrich, St. Louis, CA, USA) were added to the suspensions. Cells were incubated at $37^{\circ} \mathrm{C}$ for $1 \mathrm{~h}$, and the plasmid DNA extracted and purified following the above kit's protocol. 
Electrocompetent cells of L. lactis NZ9000, L. plantarum NC8 and L. casei LB23 were prepared according to Holo and Nes [80]. Plasmid DNA (1-2 $\mu$ g) was introduced into $75 \mu \mathrm{L}$ of electrocompetent strains using a Gene Pulser apparatus (Bio-Rad, Richmond, CA, USA) following standard protocols for Gram-positive bacteria. After electroporation, cells were suspended in $1 \mathrm{~mL}$ of fresh media and incubated at $32{ }^{\circ} \mathrm{C}$ for $2-4 \mathrm{~h}$. The cells were then plated onto appropriate media supplemented with $25 \mu \mathrm{g} \mathrm{mL}{ }^{-1}$ of either tetracycline or erythromycin and incubated under the above conditions.

Plasmid DNA from antibiotic-resistant colonies was extracted and purified following the procedure of $\mathrm{O}^{\prime}$ Sullivan and Klaenhammer [81]. To facilitate lysis, transformants were grown in GM17 (L. lactis) or MRS (L. casei and L. plantarum) supplemented with $40 \mathrm{mM}$ of DL-threonine (Merck). Plasmids were digested with restriction endonucleases as recommended by their supplier (Takara, Saint-Germain-en-Laye, France), and the resulting profiles visualized under UV light after electrophoresis in 1\% agarose gels stained with GreenSafe Premium (NZYTech, Lisboa, Portugal).

\subsection{Minimum Inhibitory Concentrations of Antibiotics}

The minimum inhibitory concentrations (MIC) of 16 antibiotics in the untransformed parental and resistant transformants were assayed by microdilution using Sensititre EULACBI1 and EULACBI2 plates (Trek Diagnostic Systems, East Grinstead, UK). Briefly, individual colonies were suspended in a sterile saline solution until reaching a density corresponding to McFarland standard $1\left(\approx 10^{8} \mathrm{cfu} \mathrm{mL}^{-1}\right)$. The suspension was then diluted 1000-fold in IsoSensitest (IST) broth (Oxoid, Basingstoke, UK) (for Lactococcus) or LSM medium (90\% IST $+10 \%$ MRS) (for lactobacilli), and $100 \mu \mathrm{L}$ of this suspension placed in each well of the Sensititre plates. These were then incubated under aerobic conditions at $32{ }^{\circ} \mathrm{C}$ for $48 \mathrm{~h}$. MICs were defined as the lowest concentration at which no visible growth was observed. For some antibiotics, the concentration range of the plates was too small to determine the actual MIC; in such cases, the MICE system (Oxoid) was used following the manufacturer's recommendations. In short, a sterile cotton swab was immersed into a sterile saline solution as above (McFarland standard 1) and used to inoculate IST or LSM agar plates. A MICE strip of the required antibiotic was placed on the plates, and incubated as above. The MIC was determined as the first concentration at which the inhibition halo contacted the antibiotic strip.

\subsection{PCR Detection of Tetracycline and Erythromycin Resistance Determinants}

The presence of tetracycline and erythromycin resistance genes was first investigated by standard PCR. Genes coding for ribosomal protection proteins conferring tetracycline resistance were targeted with the pairs of universal primers DI-DII [82] and Tet1-Tet2 [83], as well as with specific primers for tet $(\mathrm{W})[84]$, tet $(\mathrm{M})$, tet $(\mathrm{S})$, and tet $(\mathrm{O})$ [85]. Tetracycline resistance genes coding for the efflux pumps, tet $(\mathrm{K})$ and tet $(\mathrm{L})$, were also searched for using gene-specific primers [85]. The presence of erythromycin resistance genes was tested using specific primers for ermA, ermB, erm C [86], ermF [87], and mefA [88]. Amplicons were purified, sequenced, and their sequences compared to those in the NCBI database using the BLASTn tool (https: / / blast.ncbi.nlm.gov / Blast.cgi, accessed on 20 July 2021). The primer sequences, PCR conditions and expected amplicon sizes are listed in Table S2.

\subsection{Whole Plasmid DNA Sequencing, Assembly and Annotation}

Purified DNA from plasmids showing different restriction patterns were sent for sequencing to Eurofins Genomics (GATC Biotech, Constance, Germany). Individual libraries were constructed using the SPRIworks Fragment Library System I Kit (Beckman Coulter, Brea, CA, USA) and pair-end sequenced ( $2 \times 150$ bp runs) in a HiSeq sequencer (Illumina, San Diego, CA, USA). Quality-filtered reads, trimmed or non-trimmed depending on the plasmid, were de novo assembled in contigs using SPAdes v3.6.2 software [89], with a $\mathrm{k}$ value of 127 and employing the only-assembler settings. The plasmidSPAdes algorithm [90], which uses coverage as a parameter to remove chromosomal contigs, was also 
used for assembly. When plasmids were not merged into a single molecule after assembly, primers were designed based on the end of the contigs, used in PCR reactions, and the sequences of the amplicons employed to join the segments. The Vector NTI program (Invitrogen, Carlsbad, CA, USA) was used to align the sequences of contigs and PCR amplicons. The same program was used for open reading frame (ORF) prediction. Deduced protein sequences larger than 50 amino acids were compared to those in the NCBI's non-redundant protein database and manually analyzed using BLASTp.

\section{Conclusions}

In conclusion, plasmids conferring tetracycline and erythromycin resistance that were capable of replicating in LAB species were detected in Cabrales cheese-associated bacteria. For L. lactis, PCR and sequence analysis revealed tet(S) and ermB to be involved in tetracycline and erythromycin resistance, respectively. Non-specific plasmid-mediated tetracycline resistance in lactobacilli species was also observed. The detected plasmids were mosaic structures of modules bound by IS elements, the separate modules harboring genes coding for replication, mobilization, and antibiotic resistance functions. The detection of the same module in different plasmids suggests the existence of efficient module-exchanging mechanisms in LAB. The nucleotide identity of tet(S) and its flanking sequences together indicate the spread of this determinant across the cheese ecosystem to be recent. The present results reveal the potential of the procedure used in this work to detect plasmids carrying antibiotic resistance in cheese.

Supplementary Materials: The following are available online at https:/ / www.mdpi.com/article/ 10.3390/ijms22157801/s1, Figure S1: Gel electrophoresis of total plasmid DNA, Table S1: Open reading frame (ORF) analysis of tetracycline (pTC1 through pTC7) and erythromycin (pERM1) resistance plasmids. Table S2: Primers and PCR conditions utilized in this study, as well as amplicon size expected of the tetracycline and erythromycin resistance genes targeted.

Author Contributions: Conceptualization and planning of this research, B.M. and A.B.F.; performance of experimental work and preparation of the draft manuscript, A.B.F.; contribution to the experimental analysis, L.V. and J.R.; revision and edition of the manuscript, B.M., L.V., J.R. and A.B.F.; funding acquisition and material resources, B.M. and A.B.F. All authors have read and agreed to the published version of the manuscript.

Funding: This study was supported by projects from the Spanish Ministry of Economy and Competitiveness (Ref. PID2019-110549RB-I00/AEI/10.13039/501100011033) and Asturias Principality, Spain (Ref. IDI/2018/000114). A Ph.D. grant of the Severo Ochoa Program from Asturias Principality was awarded to J.R. (BP19-098).

Institutional Review Board Statement: Not applicable.

Informed Consent Statement: Not applicable.

Data Availability Statement: The nucleotide sequence data of the plasmids presented in this study (pTC1-pTC7 and pEMR1) are being submitted to the NCBI database. Until they are publicly available, sequences will be provided on request from the corresponding author.

Conflicts of Interest: The authors declare no conflict of interest. The funders had no role in the design of the study; in the collection, analyses, or interpretation of data; in the writing of the manuscript, or in the decision to publish the results.

\section{References}

1. WHO. Antimicrobial Resistance: Global Report on Surveillance. 2014. Available online: https://www.who.int/drugresistance/ documents/surveillancereport/en/ (accessed on 6 December 2019).

2. Martínez, J.L. Bottlenecks in the transferability of antibiotic resistance from natural ecosystems to human bacterial pathogens. Front. Microbiol. 2012, 2. [CrossRef]

3. Walsh, T.R. A one-health approach to antimicrobial resistance. Nat. Microbiol. 2018, 3, 854-855. [CrossRef]

4. Fletcher, S. Understanding the contribution of environmental factors in the spread of antimicrobial resistance. Environ. Health Prev. Med. 2015, 20, 243-252. [CrossRef] 
5. Prestinaci, F.; Pezzotti, P.; Pantosti, A. Antimicrobial resistance: A global multifaceted phenomenon. Pathog. Glob. Health 2015, 109, 309-318. [CrossRef] [PubMed]

6. WHO. Global Action Plan on Antimicrobial Resistance. 2015. Available online: https://apps.who.int/iris/bitstream/handle/10 665/193736/9789241509763_eng.pdf?sequence=1\&isAllowed=y (accessed on 20 January 2021).

7. Collignon, P. The importance of a One Health approach to preventing the development and spread of antibiotic resistance. Curr. Top. Microbiol. Immunol. 2013, 366, 19-36. [CrossRef] [PubMed]

8. Shintani, M.; Sanchez, Z.K.; Kimbara, K. Genomics of microbial plasmids: Classification and identification based on replication and transfer systems and host taxonomy. Front. Microbiol. 2015, 6, 242. [CrossRef] [PubMed]

9. San Millán, A.; MacLean, R.C. Fitness costs of plasmids: A limit to plasmid transmission. Microbiol. Spectr. 2017, 5. [CrossRef]

10. Rodríguez-Beltrán, J.; Dela Fuente, J.; León-Sampedro, R.; MacLean, R.C.; San Millán, Á. Beyond horizontal gene transfer: The role of plasmids in bacterial evolution. Nat. Rev. Microbiol. 2021, 19, 1-13. [CrossRef]

11. Kelleher, P.; Mahony, J.; Bottacini, F.; Lugli, G.A.; Ventura, M.; Van Sinderen, D. The Lactococcus lactis pan-plasmidome. Front. Microbiol. 2019, 10, 707. [CrossRef] [PubMed]

12. Lanza, V.F.; Tedim, A.P.; Luís Martínez, J.; Baquero, F.; Coque, T.M. The plasmidome of Firmicutes: Impact on the emergence and the spread of resistance to antimicrobials. Microbiol. Spectr. 2015, 3. [CrossRef]

13. Makarova, K.; Slesarev, A.; Wolf, Y.; Sorokin, A.; Mirkin, B.; Koonin, E.; Pavlov, A.; Pavlova, N.; Karamychev, V.; Polouchine, M.; et al. Comparative genomics of the lactic acid bacteria. Proc. Natl. Acad. Sci. USA 2006, 103, 15611-15616. [CrossRef]

14. Sørensen, S.J.; Bailey, M.; Hansen, L.H.; Kroer, N.; Wuertz, S. Studying plasmid horizontal transfer in situ: A critical review. Nat. Rev. Microbiol. 2005, 3, 700-710. [CrossRef]

15. Martínez, J.L.; Coque, T.M.; Baquero, F. What is a resistance gene? Ranking risk in resistomes. Nat. Rev. Microbiol. 2015, 13, 116-123. [CrossRef]

16. Perry, J.A.; Wright, G.D.; Roberts, M.C.; Aminov, R.I.; Degroote, M.G. The antibiotic resistance "mobilome": Searching for the link between environment and clinic. Front. Microbiol. 2013, 4, 1-12. [CrossRef] [PubMed]

17. Kumar, S.B.; Arnipalli, S.R.; Ziouzenkova, O. Antibiotics in food chain: The consequences for antibiotic resistance. Antibiotics 2020, 9, 688. [CrossRef] [PubMed]

18. Florez-Cuadrado, D.; Moreno, M.A.; Ugarte-Ruíz, M.; Domínguez, L. Antimicrobial resistance in the food chain in the European Union. Adv. Food Nutr. Res. 2018, 86, 115-136. [CrossRef]

19. Capita, R.; Alonso-Calleja, C. Antibiotic-resistant bacteria: A challenge for the food industry. Crit. Rev. Food Sci. Nutr. 2013, 53, 11-48. [CrossRef]

20. Soares-Santos, V.; Barreto, A.S.; Semedo-Lemsaddek, T. Characterization of enterococci from food and food-related settings. J. Food Prot. 2015, 78, 1320-1326. [CrossRef]

21. Flórez, A.B.; Alegría, A.; Rossi, F.; Delgado, S.; Felis, G.E.; Torriani, S.; Mayo, B. Molecular identification and quantification of tetracycline and erythromycin resistance genes in Spanish and Italian retail cheeses. BioMed Res. Int. 2014, 2014. [CrossRef]

22. Flórez, A.B.; Vázquez, L.; Mayo, B. A functional metagenomic analysis of tetracycline resistance in cheese bacteria. Front. Microbiol. 2017, 8, 907. [CrossRef]

23. Flórez, A.B.; Campedelli, I.; Delgado, S.; Alegría, Á.; Salvetti, E.; Felis, G.E.; Mayo, B.; Torriani, S. Antibiotic susceptibility profiles of dairy Leuconostoc, analysis of the genetic basis of atypical resistances and transfer of genes in vitro and in a food matrix. PLoS ONE 2016, 11, e0145203. [CrossRef]

24. Flórez, A.B.; Ammor, M.S.; Mayo, B. Identification of tet(M) in two Lactococcus lactis strains isolated from a Spanish traditional starter-free cheese made of raw milk and conjugative transfer of tetracycline resistance to lactococci and enterococci. Int. J. Food Microbiol. 2008, 121, 189-194. [CrossRef]

25. Madec, J.Y.; Haenni, M. Antimicrobial resistance plasmid reservoir in food and food-producing animals. Plasmid 2018, 99 , 72-81. [CrossRef]

26. McMillan, E.A.; Gupta, S.K.; Williams, L.E.; Jové, T.; Hiott, L.M.; Woodley, T.A.; Barrett, J.B.; Jackson, C.R.; Wasilenko, J.L.; Simmons, M.; et al. Antimicrobial resistance genes, cassettes, and plasmids present in Salmonella enterica associated with United States food animals. Front. Microbiol. 2019, 10, 832. [CrossRef] [PubMed]

27. Tarazanova, M.; Beerthuyzen, M.; Siezen, R.; Fernandez-Gutierrez, M.M.; de Jong, A.; van der Meulen, S.; Kok, J.; Bachmann, H. Plasmid complement of Lactococcus lactis NCDO712 reveals a novel pilus gene cluster. PLoS ONE 2016, 11, e0167970. [CrossRef]

28. Ainsworth, S.; Stockdale, S.; Bottacini, F.; Mahony, J.; van Sinderen, D. The Lactococcus lactis plasmidome: Much learnt, yet still lots to discover. FEMS Microbiol. Rev. 2014, 38, 1066-1088. [CrossRef]

29. Walsh, A.M.; Macori, G.; Kilcawley, K.N.; and Cotter, P.D. Meta-analysis of cheese microbiomes highlights contributions to multiple aspects of quality. Nat. Food 2020, 1, 500-510. [CrossRef]

30. Peterson, E.; Kaur, P. Antibiotic resistance mechanisms in bacteria: Relationships between resistance determinants of antibiotic producers, environmental bacteria, and clinical pathogens. Front. Microbiol. 2018, 9, 2928. [CrossRef] [PubMed]

31. Flórez, A.B.; Mayo, B. Antibiotic resistance-susceptibility profiles of Streptococcus thermophilus isolated from raw milk and genome analysis of the genetic basis of acquired resistances. Front. Microbiol. 2017, 8, 2608. [CrossRef] [PubMed]

32. Ammor, M.S.; Flórez, A.B.; van Hoek, A.H.; de Los Reyes-Gavilán, C.G.; Aarts, H.J.; Margolles, A.; Mayo, B. Molecular characterization of intrinsic and acquired antibiotic resistance in lactic acid bacteria and bifidobacteria. J. Mol. Microbiol. Biotechnol. 2008, 14, 6-15. [CrossRef] 
33. Maki, T.; Santos, M.D.; Kondo, H.; Hirono, I.; Aoki, T. A transferable 20-kilobase multiple drug resistance-conferring R plasmid (pKL0018) from a fish pathogen (Lactococcus garvieae) is highly homologous to a conjugative multiple drug resistance-conferring enterococcal plasmid. Appl. Environ. Microbiol. 2009, 75, 3370-3372. [CrossRef]

34. Raha, A.R.; Ross, E.; Yusoff, K.; Manap, M.Y.; Ideris, A. Characterisation and molecular cloning of an erythromycin resistance plasmid of Lactococcus lactis isolated from chicken cecum. J. Biochem. Mol. Biol. Biophys. 2020, 6, 7-11. [CrossRef]

35. Biggel, M.; Zurfluh, K.; Treier, A.; Nüesch-Inderbinen, M.; Stephan, R. Characteristics of fosA-carrying plasmids in E. coli and Klebsiella spp. isolates originating from food and environmental samples. J. Antimicrob. Chemother. 2021, 76, 2004-2011. [CrossRef]

36. Liu, Y.; Wang, Y.; Schwarz, S.; Li, Y.; Shen, Z.; Zhang, Q.; Wu, C.; Shen, J. Transferable multiresistance plasmids carrying $c f r$ in Enterococcus spp. from swine and farm environment. Antimicrob. Agents Chemother. 2013, 57, 42-48. [CrossRef]

37. Loftie-Eaton, W.; Crabtree, A.; Perry, D.; Millstein, J.; Baytosh, J.; Stalder, T.; Robison, B.D.; Forney, L.J.; Top, E.M. Contagious antibiotic resistance: Plasmid transfer among bacterial residents of the zebrafish gut. Appl. Environ. Microbiol. 2021, 87. [CrossRef] [PubMed]

38. Chaslus-Dancla, E.; Gerbaud, G.; Lagorce, M.; Lafont, J.P.; Courvalin, P. Persistence of an antibiotic resistance plasmid in intestinal Escherichia coli of chickens in the absence of selective pressure. Antimicrob. Agents Chemother. 1987, 31, 784-788. [CrossRef]

39. Hayashi, W.; Yoshida, S.; Izumi, K.; Koide, S.; Soga, E.; Takizawa, S.; Arakawa, Y.; Nagano, Y.; Nagano, N. Genomic characterisation and epidemiology of nosocomial Serratia marcescens isolates resistant to ceftazidime and their plasmids mediating rare blaTEM-61. J. Glob. Antimicrob. Resist. 2021, 25, 124-131. [CrossRef]

40. Pietsch, M.; Pfeifer, Y.; Fuchs, S.; Werner, G. Genome-based analyses of fitness effects and compensatory changes associated with acquisition of bla $\mathrm{CMY}^{-}$, bla $\mathrm{CTX}_{-\mathrm{M}^{-}}$, and bla $\mathrm{OXA}-48 / \mathrm{VIM}-1^{-}$containing plasmids in Escherichia coli. Antibiotics 2021, 10, 90. [CrossRef] [PubMed]

41. Tyson, G.H.; Sabo, J.L.; Hoffmann, M.; Hsu, C.H.; Mukherjee, S.; Hernandez, J.; Tillman, G.; Wasilenko, J.L.; Haro, J.; Simmons, M.; et al. Novel linezolid resistance plasmids in Enterococcus from food animals in the USA. J. Antimicrob. Chemother. 2018, 73, 3254-3258. [CrossRef]

42. ESVAC. Sales of Veterinary Antimicrobial Agents in 31 European Countries in 2018. Tenth ESVAC Report. 2020. Available online: https:/ / www.ema.europa.eu/en/documents/report/sales-veterinary-antimicrobial-agents-31-european-countries-20 18-trends-2010-2018-tenth-esvac-report_en.pdf (accessed on 15 December 2020).

43. Devirgiliis, C.; Caravelli, A.; Coppola, D.; Barile, S.; Perozzi, G. Antibiotic resistance and microbial composition along the manufacturing process of Mozzarella di Bufala Campana. Int. J. Food Microbiol. 2008, 128, 378-384. [CrossRef]

44. Ammor, M.S.; Flórez, A.B.; Mayo, B. Antibiotic resistance in non-enterococcal lactic acid bacteria and bifidobacteria. Food Microbiol. 2007, 24. [CrossRef]

45. Van Hoek, A.H.A.M.; Mevius, D.; Guerra, B.; Mullany, P.; Roberts, A.P.; Aarts, H.J.M. Acquired antibiotic resistance genes: An overview. Front. Microbiol. 2011, 2, 203. [CrossRef]

46. Rao Thumu, S.C.; Halami, P.M. Presence of erythromycin and tetracycline resistance genes in lactic acid bacteria from fermented foods of Indian origin. Antonie Leeuwenhoek 2012, 102, 541-551. [CrossRef]

47. Pinto, U.M.; Pappas, K.M.; Winans, S.C. The ABCs of plasmid replication and segregation. Nat. Rev. Microbiol. 2021, 10, 755-765. [CrossRef] [PubMed]

48. Sørvig, E.; Skaugen, M.; Naterstad, K.; Eijsink, V.G.H.; Axelsson, L. Plasmid p256 from Lactobacillus plantarum represents a new type of replicon in lactic acid bacteria, and contains a toxin-antitoxin-like plasmid maintenance system. Microbiology 2005, 151, 421-431. [CrossRef] [PubMed]

49. Van Mastrigt, O.; Di Stefano, E.; Hartono, S.; Abee, T.; Smid, E.J. Large plasmidome of dairy Lactococcus lactis subsp. lactis biovar diacetylactis FM03P encodes technological functions and appears highly unstable. BMC Genom. 2018, 19, 620. [CrossRef]

50. Siezen, R.J.; Renckens, B.; Van Swam, I.; Peters, S.; Van Kranenburg, R.; Kleerebezem, M.; De Vos, W.M. Complete sequences of four plasmids of Lactococcus lactis subsp. cremoris SK11 reveal extensive adaptation to the dairy environment. Appl. Environ. Microbiol. 2005, 71, 8371-8382. [CrossRef] [PubMed]

51. Seegers, J.F.M.L.; Bron, S.; Franke, C.M.; Venema, G.; Kiewiet, R. The majority of lactococcal plasmids carry a highly related replicon. Microbiology 1994, 140, 1291-1300. [CrossRef] [PubMed]

52. Del Solar, G.; Giraldo, R.; Ruiz-Echevarría, M.J.; Espinosa, M.; Díaz-Orejas, R. Replication and control of circular bacterial plasmids. Microbiol. Mol. Biol. Rev. 1998, 62, 434-464. [CrossRef] [PubMed]

53. Flórez, A.B.; Mayo, B. Diversity and dynamics of antibiotic-resistant bacteria in cheese as determined by PCR denaturing gradient gel electrophoresis. Int. J. Food Microbiol. 2015, 214, 63-69. [CrossRef]

54. Alexa Oniciuc, E.A.; Walsh, C.J.; Coughlan, L.M.; Awad, A.; Simon, C.A.; Ruiz, L.; Crispie, F.; Cotter, P.D.; Alvarez-Ordóñez, A. Dairy products and dairy-processing environments as a reservoir of antibiotic resistance and quorum-quenching determinants as revealed through functional metagenomics. mSystems 2020, 5, e00723-19. [CrossRef] [PubMed]

55. Russo, N.; Caggia, C.; Pino, A.; Coque, T.M.; Arioli, S.; Randazzo, C.L. Enterococcus spp. in Ragusano PDO and Pecorino Siciliano cheese types: A snapshot of their antibiotic resistance distribution. Food Chem. Toxicol. 2018, 120, 277-286. [CrossRef] [PubMed]

56. Rodrigues, M.X.; Silva, N.C.C.; Trevilin, J.H.; Cruzado, M.M.B.; Mui, T.S.; Duarte, F.R.S.; Castillo, C.J.C.; Canniatti-Brazaca, S.G.; Porto, E. Molecular characterization and antibiotic resistance of Staphylococcus spp. isolated from cheese processing plants. J. Dairy Sci. 2017, 100, 5167-5175. [CrossRef] [PubMed] 
57. Kelly, W.J.; Ward, L.J.H.; Leahy, S.C. Chromosomal diversity in Lactococcus lactis and the origin of dairy starter cultures. Genome Biol. Evol. 2010, 2, 729-744. [CrossRef]

58. Porse, A.; Schønning, K.; Munck, C.; Sommer, M.O.A. Survival and evolution of a large multidrug resistance plasmid in new clinical bacterial hosts. Mol. Biol. Evol. 2016, 33, 2860-2873. [CrossRef] [PubMed]

59. Flórez, A.B.; Mayo, B. The plasmid complement of the cheese isolate Lactococcus garvieae IPLA 31405 revealed adaptation to the dairy environment. PLOS ONE 2015, 10, e0126101. [CrossRef] [PubMed]

60. Van Kranenburg, R.; Golic, N.; Bongers, R.; Leer, R.J.; De Vos, W.M.; Siezen, R.J.; Kleerebezem, M. Functional analysis of three plasmids from Lactobacillus plantarum. Appl. Environ. Microbiol. 2005, 71, 1223-1230. [CrossRef]

61. Erkus, O.; De Jager, V.C.L.; Spus, M.; Van Alen-Boerrigter, I.J.; Van Rijswijck, I.M.H.; Hazelwood, L.; Janssen, P.W.M.; Van Hijum, S.A.F.T.; Kleerebezem, M.; Smid, E.J. Multifactorial diversity sustains microbial community stability. ISME J. 2013, 7, $2126-2136$. [CrossRef]

62. Lee, Y.; Nguyen, T.L.; Kim, A.; Kim, N.; Roh, H.J.; Han, H.J.; Jung, S.H.; Cho, M.Y.; Kang, H.Y.; Kim, D.H. Complete genome sequence of multiple-antibiotic-resistant Streptococcus parauberis strain SPOF3K, isolated from diseased olive flounder (Paralichthys olivaceus). Genome Announc. 2018, 6. [CrossRef]

63. Teuber, M.; Meile, L.; Schwarz, F. Acquired antibiotic resistance in lactic acid bacteria from food. Antonie Leeuwenhoek 1999, 76, 115-137. [CrossRef]

64. Chanchaithong, P.; Perreten, V.; Schwendener, S. Macrococcus canis contains recombinogenic methicillin resistance elements and the mecB plasmid found in Staphylococcus aureus. J. Antimicrob. Chemother. 2019, 74, 2531-2536. [CrossRef] [PubMed]

65. Ferrand, A.; Vergalli, J.; Pagès, J.M.; Davin-Regli, A. An intertwined network of regulation controls membrane permeability including drug influx and efflux in Enterobacteriaceae. Microorganisms 2020, 8, 833. [CrossRef]

66. Putman, M.; van Veen, H.W.; Konings, W.N. Molecular properties of bacterial multidrug transporters. Microbiol. Mol. Biol. Rev. 2000, 64, 672-693. [CrossRef] [PubMed]

67. Nawaz, M.; Wang, J.; Zhou, A.; Ma, C.; Wu, X.; Moore, J.E.; Millar, B.C.; Xu, J. Characterization and transfer of antibiotic resistance in lactic acid bacteria from fermented food products. Curr. Microbiol. 2011, 62, 1081-1089. [CrossRef]

68. Schwarz, F.V.; Perreten, V.; Teuber, M. Sequence of the 50-kb conjugative multiresistance plasmid pRE25 from Enterococcus faecalis RE25. Plasmid 2001, 46, 170-187. [CrossRef]

69. Chantziaras, I.; Boyen, F.; Callens, B.; Dewulf, J. Correlation between veterinary antimicrobial use and antimicrobial resistance in food-producing animals: A report on seven countries. J. Antimicrob. Chemother. 2014, 69, 827-834. [CrossRef]

70. Yazdankhah, S.; Rudi, K.; Bernhoft, A. Zinc and copper in animal feed-development of resistance and co-resistance to antimicrobial agents in bacteria of animal origin. Microb. Ecol. Health Dis. 2014, 25, 25862. [CrossRef]

71. Fernández-Fuentes, M.A.; Ortega Morente, E.; Abriouel, H.; Pérez Pulido, R.; Gálvez, A. Isolation and identification of bacteria from organic foods: Sensitivity to biocides and antibiotics. Food Control 2012, 26, 73-78. [CrossRef]

72. Amachawadi, R.G.; Shelton, N.W.; Shi, X.; Vinasco, J.; Dritz, S.S.; Tokach, M.D.; Nelssen, J.L.; Scott, H.M.; Nagaraja, T.G. Selection of fecal enterococci exhibiting tcrB-mediated copper resistance in pigs fed diets supplemented with copper. Appl. Environ. Microbiol. 2011, 77, 5597-5603. [CrossRef]

73. Hasman, H.; Aarestrup, F.M. Relationship between copper, glycopeptide, and macrolide resistance among Enterococcus faecium strains isolated from pigs in Denmark between 1997 and 2003. Antimicrob. Agents Chemother. 2005, 49, 454-456. [CrossRef]

74. Sachi, S.; Ferdous, J.; Sikder, M.H.; Azizul Karim Hussani, S.M. Antibiotic residues in milk: Past, present, and future. J. Adv. Vet. Anim. Res. 2019, 6, 315-332. [CrossRef] [PubMed]

75. Zwierzchowski, G.; Ametaj, B.N. Minerals and heavy metals in the whole raw milk of dairy cows from different management systems and countries of origin: A meta-analytical study. J. Agric. Food Chem. 2018, 66, 6877-6888. [CrossRef] [PubMed]

76. Schwaiger, K.; Harms, K.S.; Bischoff, M.; Preikschat, P.; Mölle, G.; Bauer-Unkauf, I.; Lindorfer, S.; Thalhammer, S.; Bauer, J.; Hölzel, C.S. Insusceptibility to disinfectants in bacteria from animals, food and humans-is there a link to antimicrobial resistance? Front. Microbiol. 2014, 5. [CrossRef] [PubMed]

77. Díaz-Orejas, R.; Espinosa, M.; Yeo, C.C. The importance of the expendable: Toxin-antitoxin genes in plasmids and chromosomes. Front. Microbiol. 2017, 8, 1479. [CrossRef] [PubMed]

78. Gama, J.A.; Zilhão, R.; Dionisio, F. Impact of plasmid interactions with the chromosome and other plasmids on the spread of antibiotic resistance. Plasmid 2018, 99, 82-88. [CrossRef]

79. Carroll, A.C.; Wong, A. Plasmid persistence: Costs, benefits, and the plasmid paradox. Can. J. Microbiol. 2018, 64, 293-304. [CrossRef]

80. Holo, H.; Nes, I.F. High-frequency transformation, by electroporation, of Lactococcus lactis subsp. cremoris grown with glycine in osmotically stabilized media. Appl. Environ. Microbiol. 1989, 55, 3119-3123. [CrossRef]

81. O'Sullivan, D.J.; Klaenhammer, T.R. Rapid mini-prep isolation of high-quality plasmid DNA from Lactococcus and Lactobacillus spp. Appl. Environ. Microbiol. 1993, 59, 2730-2733. [CrossRef]

82. Clermont, D.; Chesneau, O.; De Cespédès, G.; Horaud, T. New tetracycline resistance determinants coding for ribosomal protection in streptococci and nucleotide sequence of tet(T) isolated from Streptococcus pyogenes A498. Antimicrob. Agents Chemother. 1997, 41, 112-116. [CrossRef]

83. Barbosa, T.M.; Scott, K.P.; Flint, H.J. Evidence for recent intergeneric transfer of a new tetracycline resistance gene, tet(W), isolated from Butyrivibrio fibrisolvens, and the occurrence of tet $(\mathrm{O})$ in ruminai bacteria. Environ. Microbiol. 1999, 1, 53-64. [CrossRef] 
84. Scott, K.P.; Melville, C.M.; Barbosa, T.M.; Flint, H.J. Occurrence of the new tetracycline resistance gene tet $(\mathrm{W})$ in bacteria from the human gut. Antimicrob. Agents Chemother. 2000, 44, 775-777. [CrossRef] [PubMed]

85. Gevers, D.; Danielsen, M.; Huys, G.; Swings, J. Molecular characterization of tet(M) genes in Lactobacillus isolates from different types of fermented dry sausage. Appl. Environ. Microbiol. 2003, 69, 1270-1275. [CrossRef]

86. Jensen, L.B.; Frimodt-Møller, N.; Aarestrup, F.M. Presence of erm gene classes in Gram-positive bacteria of animal and human origin in Denmark. FEMS Microbiol. Lett. 1999, 170, 151-158. [CrossRef]

87. Roberts, M.C.; Chung, W.O.; Roe, D.; Xia, M.; Marquez, C.; Borthagaray, G.; Whittington, W.L.; Holmes, K.K. Erythromycinresistant Neisseria gonorrhoeae and oral commensal Neisseria spp. carry known rRNA methylase genes. Antimicrob. Agents Chemother. 1999, 43, 1367-1372. [CrossRef]

88. Luna, V.A.; Cousin, S., Jr.; Whittington, W.L.; Roberts, M.C. Identification of the conjugative mef gene in clinical Acinetobacter junii and Neisseria gonorrhoeae isolates. Antimicrob. Agents Chemother. 2000, 44, 2503-2506. [CrossRef]

89. Bankevich, A.; Nurk, S.; Antipov, D.; Gurevich, A.A.; Dvorkin, M.; Kulikov, A.S.; Lesin, V.M.; Nikolenko, S.I.; Pham, S.; Prjibelski, A.D.; et al. SPAdes: A new genome assembly algorithm and its applications to single-cell sequencing. J. Comput. Biol. 2012, 19, 455-477. [CrossRef]

90. Antipov, D.; Hartwick, N.; Shen, M.; Raiko, M.; Lapidus, A.; Pevzner, P.A. PlasmidSPAdes: Assembling plasmids from whole genome sequencing data. Bioinformatics 2016, 32, 3380-3387. [CrossRef] 